\title{
Welfare Indicators of Milking Sheep and Goats in Commercial Farms in Spain: Evaluation and Differences among Species, Locations and Performances
}

\author{
Bello JMM ${ }^{1}$, Arroyo G ${ }^{1}$, Ruiz S1, Gonzalez G ${ }^{1}$, Marques F ${ }^{1}$, Mantecon AR ${ }^{2}$ and Lavin P $^{2}$ \\ ${ }^{1}$ Nanta S.A. Ronda de Poniente, Tres Cantos. Madrid, Spain \\ ${ }^{2}$ IGM-CSIC-ULE, Finca Marzanas, Grulleros, León, Spain
}

Corresponding author: Bello JM, Nanta S.A. Ronda de Poniente, 9. 28460 Tres Cantos. Madrid, Spain, E-mail: jm.bello@nutreco.com

Rec date: May 21, 2016; Acc date: June 02, 2016; Pub date: June 09, 2016

Copyright: (C 2016 Bello JM, et al. This is an open-access article distributed under the terms of the Creative Commons Attribution License, which permits unrestricted use, distribution, and reproduction in any medium, provided the original author and source are credited.

Citation: Bello JM, Arroyo G, Ruiz S, Gonzalez G, Marques F, et al. Welfare Indicators of Milking Sheep and Goats in Commercial Farms in Spain: Evaluation and Differences among Species, Locations and Performances. J Anim Nutr 2016, 1:4

\section{Abstract}

The objective of this work was to evaluate a system for assessing the welfare of milking sheep and goats in practical farm conditions. The system uses indicators of environmental, management and facilities related welfare. In order to evaluate the animal welfare, 12 indicators ranked in 3 groups were defined: Environment Animal Welfare (EAW, $n=4)$ (temperature, airflow, ventilation and ammonia load) Management Animal Welfare (MAW, $\mathrm{n}=5$ ) (animal load, bedding, comfort, stress and cleanness of animals) and Facilities Animal Welfare (FAW, $\mathrm{n}=3$ ) (feeders of concentrate, feeders of forage and watering). All indicators were evaluated from 1 to 10 taking into account objective and subjective criteria. In addition, the average of scores of the three groups (EAW, MAW, and FAW) and the Global Animal Welfare (GAW) score (the average of all the indicators) were also calculated.

One hundred and one assessments (49 in goat and 52 in sheep) were carried out in intensive farms in Spain from 2005 to 2011.

The indicators were then compared by farm size, geographical location and production level of the farms. Results obtained show the relationships between the welfare indicators and the zoo technical characteristics of the farms.

\section{Keywords: Welfare; Farms; Sheep; Goats}

\section{Introduction}

The importance of animal welfare in the animal production industry is growing increasingly, not only by legal requirements but for its effects on productivity. Only if the animals are in a proper degree of comfort can be achieved optimal production levels [1]. However, the assessment of animal welfare in commercial dairy goats and sheep intensive farms is not well defined yet [2]. Several procedures to assess the animal welfare have been proposed worldwide [3-6]. In addition, according to Dungey [7], qualitative welfare assessment procedures are reliable and have been used in sheep. In all cases, indicators should be valid, reliable, economical and measurable in practical conditions [8]. The aim of this study is to assess the system proposed by Nanta to measure welfare of sheep and goat milking flocks, in practical operating conditions. The variations of the parameters set up, depending on the Spanish region, farm size and level of production have also studied.

\section{Material and Methods}

One hundred and one welfare assessments ( 49 goats and 52 sheep) in 71 intensive dairy farms (34 sheep and 37 goats) were carried out in Spain from 2005 to 2011. Although more than one assessment was made in several farms, the evaluations were carried out in different years. Therefore we consider every assessment as an individual farm.

In order to evaluate the animal welfare, 12 indicators ranked in 3 groups were defined: Environment Animal Welfare (EAW, $n=4$ ) (temperature, airflow, ventilation and ammonia load), Management Animal Welfare (MAW, $\mathrm{n}=5$ ) (animal load, bedding, comfort, stress and cleanness of animals) and Facilities Animal Welfare (FAW, $n=3$ ) (feeders of concentrate, feeders of forage and watering). All indicators were evaluated from 1 to 10 taking into account objective and subjective criteria.

In addition, the average of scores of the three groups (EAW, MAW and FAW) and the Global Animal Welfare (GAW) score (the average of all the indicators) were also calculated. The score of several feeding indicators (body condition score and faeces consistency, both of them scored from 1 to 5) were also collected from each farm (scoring only a sample of animals with a one value per farm).

Some productive performance data were taken from each farm: production yield (litters/animal.day), milk composition (fat (\%), protein (\%), fat plus protein (\%), somatic cells (ufc $\left.{ }^{*} 1000 / \mathrm{ml}\right)$ and daily production of fat $(\mathrm{g} /$ day), protein $(\mathrm{g} /$ 
day) and fat plus protein extract (g/day). Average values of productive parameters for sheep and goats, respectively, were: $1.8 \pm 0.08,2.2 \pm 0.09$ litters/animal.day, $6.7 \pm 0.21,5.0 \pm$ 0.13 fat $(\%), 5.1 \pm 0.14,3.7 \pm 0.10$ protein $(\%)$ and $910.6 \pm$ $58.39,1341.6 \pm 112.32$ somatic cell ${ }^{*} 1000 / \mathrm{ml}$.
The evaluation criteria of every indicator are shown in Table 1. Scores lower than 3 and bigger than 8 are related to deficient and excellent conditions of welfare respectively (according to the evaluator criteria).

Table 1: Evaluation criteria of every indicator.

\begin{tabular}{|c|c|c|c|}
\hline \multirow{4}{*}{$\begin{array}{l}\text { Indicator } \\
\text { Temperature }\end{array}$} & \multirow{4}{*}{$\begin{array}{r}\text { Concept } \\
\text { At the moment of assessment }\end{array}$} & \multicolumn{2}{|c|}{ Score Criteria } \\
\hline & & $3-4$ & $<1^{\circ} \mathrm{C}$ and $>32^{\circ} \mathrm{C}$ \\
\hline & & $5-6$ & Between $1^{\circ} \mathrm{C}$ and $15^{\circ} \mathrm{C}$ and $25^{\circ} \mathrm{C}-2^{\circ} \mathrm{C}$ \\
\hline & & $7-8$ & Between $15^{\circ} \mathrm{C}$ and $25^{\circ} \mathrm{C}$ \\
\hline \multirow[t]{3}{*}{ Airflow } & \multirow[t]{3}{*}{ Incidence or intensity of airflow } & $3-4$ & Air directly at the animals or high intensity \\
\hline & & $5-6$ & Evidence of airflow but animals protected \\
\hline & & $7-8$ & Not airflow \\
\hline \multirow[t]{5}{*}{ Ventilation } & \multirow{5}{*}{$\begin{array}{l}\text { Air volume/Animal. Input and output of air } \\
\text { (Surface) }\end{array}$} & $3-4$ & Volume of air $<4 \mathrm{~m}^{3} /$ animal. \\
\hline & & $5-6$ & Input surface $<0.04 \mathrm{~m}^{2} /$ animal. \\
\hline & & $7-8$ & Output surface $<0.02 \mathrm{~m}^{2}$ /animal \\
\hline & & & One of the two conditions accomplished \\
\hline & & & Both conditions accomplished \\
\hline \multirow[t]{3}{*}{ Ammonia Load } & \multirow{3}{*}{$\begin{array}{l}\text { Gas and ammonia load Trought Olfactory } \\
\text { perception }\end{array}$} & $3-4$ & High perception and irritation of eyes \\
\hline & & $5-6$ & Smell perception. Smell remains in clothes \\
\hline & & $7-8$ & Not smell. Smell does not remain on clothes \\
\hline \multirow[t]{3}{*}{ Animal Load } & \multirow[t]{3}{*}{$N^{\circ}$ of Animal per square meter } & $3-4$ & $>1.0 \mathrm{~m}^{2} /$ animal \\
\hline & & $5-6$ & Between 1.0 and $1.5 \mathrm{~m}^{2}$ per animal \\
\hline & & $7-8$ & $>1.5 \mathrm{~m}^{2}$ /animal \\
\hline \multirow[t]{3}{*}{ Bedding } & \multirow[t]{3}{*}{ Cleanness, Amount and Dryness of Bed } & $3-4$ & Low amount, high Humidity, dirty bed (at least two conditions) \\
\hline & & $5-6$ & Bed clean and dry \\
\hline & & $7-8$ & Bed clean, dry and high amount \\
\hline \multirow[t]{3}{*}{ Comfort } & Humidity & $3-4$ & Not isolation. High Humidity level \\
\hline & Noise & $5-6$ & Good isolation and normal level of humidity \\
\hline & Distances & $7-8$ & In addition, there should not be high distances in the pen. \\
\hline \multirow[t]{3}{*}{ Stress } & \multirow[t]{3}{*}{ Behaviour and Stereotypes } & $3-4$ & $>60 \%$ of animals standing. There are evidence of stereotypes \\
\hline & & $5-6$ & $60-80 \%$ of animals lying. Stereotypes not observed \\
\hline & & $7-8$ & $>80 \%$ of animals lying \\
\hline \multirow[t]{3}{*}{ Cleanness of Animals } & \multirow[t]{3}{*}{ Cleanness in Hair and Legs } & $3-4$ & Hair and legs clearly dirty \\
\hline & & $5-6$ & Hair clean and legs dirty below hocks \\
\hline & & $7-8$ & Hair and legs clearly clean \\
\hline \multirow[t]{3}{*}{ Feeders of Concentrate } & \multirow[t]{3}{*}{ Length and Cleanness } & $3-4$ & $<0.33 \mathrm{~m}$ per animal or dirty feeder \\
\hline & & $5-6$ & $>0.33 \mathrm{~m}$ per animal. Cleanness and proper feed \\
\hline & & $7-8$ & $>0.5 \mathrm{~m}$ per animal. Cleanness and proper feed \\
\hline \multirow[t]{3}{*}{ Feeders of Forage } & \multirow[t]{3}{*}{ Length, Cleanness and Amount of Forage } & $3-4$ & $<0.33 \mathrm{~m}$ per animal or dirty feeder \\
\hline & & $5-6$ & $>0.33 \mathrm{~m}$ per animal. Cleanness and forage available \\
\hline & & $7-8$ & $>0.5 \mathrm{~m}$ per animal. Cleanness and forage available \\
\hline \multirow[t]{3}{*}{ Watering } & \multirow[t]{3}{*}{ Amount, Cleanness and Availability } & $3-4$ & $<1$ trough/30 animals or $<1 \mathrm{~m} / 100$ animals, or dirt etc. \\
\hline & & $5-6$ & $>1$ trough/30 animals or $>1 \mathrm{~m} / 100$ animals. Cleanness \\
\hline & & $7-8$ & In addition, not big distances for watering \\
\hline
\end{tabular}

In order to study the effect of the size of flock on the animal welfare, the farms were classified in three groups: small, medium and large. The distribution of the farms studied according its size and regions are showed in Tables 2 and 3. 
The number of animals is expressed in average of animals per assessment.

Table 2: Distribution of the farms in groups of size.

\begin{tabular}{|l|c|c|c|}
\hline \multicolumn{2}{|c|}{ Size range ( ${ }^{\circ}$ animals/farm assessment) } \\
\hline & Small & Medium & Large \\
\hline Sheep & $250-400(n=17)$ & $401-1000(n=17)$ \\
\hline Ewes/farm & $353,1 \pm 12,14$ & $686,7 \pm 50,11$ & $301-500(n=14)$ \\
\hline Goat & $150-300(n=23)$ & $395,7 \pm 10,68$ \\
\hline Goats/farm & $263,9 \pm 10,33$ & $>500(n=12)$ \\
\hline
\end{tabular}

The statistical analysis was conducted using SPSS 19 for Windows (SPSS Inc., IBM Corporation, NY, USA). One-way ANOVA analysis was applied to test differences between species and size of flocks (animal amount). The effects of each indicator, EAW, MAW, FAW and GAW on the productive performance were also studied. Linear correlations among total parameters were carried out using deseing program. Significance was declared at $p<0.05$ and trend was declared at $p<0.10$.

Table 3: Distribution of farms (number of farms) by species and region.

\begin{tabular}{|l|c|c|c|c|c|c|}
\hline & Aragón & Andalucía & Castilla y León & Centro & Valencia & Others \\
\hline Total & 20 & 16 & 16 & 17 & 21 \\
\hline Sheep & 18 & 3 & 13 & 9 & 5 & 4 \\
\hline Goat & 2 & 13 & 3 & 8 & 6 & 17 \\
\hline
\end{tabular}

\section{Results and Discussion}

$(6.04 \pm 0.064)$ and for FAW $(6.0 \pm 0.07)$. The EAW indicators got Concerning GAW, only $2 \%$ of farms were scored under 5 . range from 1 to 8 ) and bedding (score range from 3 to 9 ) (Table The MAW was the best scored $(6.2 \pm 0.08)$, followed by EAW 4).

Table 4: Average, maximum and minimum score of indicators.

\begin{tabular}{|c|c|c|c|}
\hline & Total & Minimum & Maximum \\
\hline Environmental Animal Welfare (EAW) (a) & 6.04 & 4.5 & 7.75 \\
\hline Temperature & 6.28 & 4 & 8.0 \\
\hline Airflow & 6.41 & 4 & 8.0 \\
\hline Ventilation & 5.81 & 4 & 8 \\
\hline Ammonia load & 5.66 & 4 & 8 \\
\hline Management Animal Welfare (MAW) (b) & 6.17 & 3.6 & 8.2 \\
\hline Animal load & 6.14 & 3 & 8 \\
\hline Bedding & 6.27 & 3 & 9 \\
\hline Comfort & 6.06 & 4 & 9 \\
\hline Stress & 5.81 & 1 & 8 \\
\hline Cleanness of animals & 6.59 & 4 & 8 \\
\hline Facilities Animal Welfare (FAW) (c) & 5.96 & 4.33 & 8 \\
\hline Feeders of concéntrate & 5.95 & 4 & 8 \\
\hline Feeders of forage & 6.05 & 4 & 8 \\
\hline
\end{tabular}




\begin{tabular}{|l|c|c|c|}
\hline Watering & 5.87 & 3 \\
\hline Others indicators & 3.5 & 2 & 4 \\
\hline Feces consistency (1-5) & 3.04 & 2 & 4 \\
\hline Body condition score (1-5) & 6.08 & 4.75 & 7.75 \\
\hline Global Animal Welfare (GAW) (a+b+c) & & \multicolumn{2}{|c|}{8} \\
\hline
\end{tabular}

Among species (Table 5), goats were better scored ( $p<$ 0.001 ) in cleanness of animals (goat $6.9 \pm 0.01$ and sheep $6.3 \pm$ 0.13 ) and $(p<0.1)$ in MAW (goat $6.3 \pm 0.09$, sheep $6.0 \pm 0.12$ ).
However EAW was better scored in sheep (sheep $6.1 \pm 0.09$, goat $5.9 \pm 0.09)$.

Table 5: Welfare indicators for dairy sheep and goat flocks according the size of the farms.

\begin{tabular}{|c|c|c|c|c|c|c|c|c|}
\hline & \multicolumn{4}{|c|}{ Sheep } & \multicolumn{4}{|c|}{ Goat } \\
\hline & Small & Medium & Large & $\mathbf{p}$ & Small & Medium & Large & $\mathbf{p}$ \\
\hline $\mathrm{N}^{\circ}$ Animals & $\begin{array}{l}353.1^{a} \\
\pm 12.14\end{array}$ & $\begin{array}{l}686.7^{b} \\
\pm 50.11\end{array}$ & $\begin{array}{l}1861.1^{\mathrm{c}} \\
\pm 192.19\end{array}$ & $* * *$ & $\begin{array}{l}263.9^{a} \\
\pm 10.33\end{array}$ & $\begin{array}{l}395.7^{b} \\
\pm 10.68\end{array}$ & $\begin{array}{l}825.0^{c} \\
\pm 80.83\end{array}$ & *** \\
\hline Airflow & $\begin{array}{l}6.13^{a} \\
\pm 0.155\end{array}$ & $\begin{array}{l}6.80^{\mathrm{b}} \\
\pm 0.145\end{array}$ & $\begin{array}{l}6.56^{\mathrm{ab}} \\
\pm 0.217\end{array}$ & * & $\begin{array}{l}6.26 \\
\pm 0.169\end{array}$ & $\begin{array}{l}6.43 \\
\pm 0.202\end{array}$ & $\begin{array}{l}6.33 \\
\pm 0.188\end{array}$ & ns \\
\hline Animal load & $\begin{array}{l}5.25^{a} \\
\pm 0.393\end{array}$ & $\begin{array}{l}6.27^{\mathrm{b}} \\
\pm 0.228\end{array}$ & $\begin{array}{l}6.39^{\mathrm{b}} \\
\pm 0.231\end{array}$ & * & $\begin{array}{l}6.13 \\
\pm 0.202\end{array}$ & $\begin{array}{l}6.43 \\
\pm 0.202\end{array}$ & $\begin{array}{l}6.58 \\
\pm 0.229\end{array}$ & ns \\
\hline Feeders of concentrate & $\begin{array}{l}5.56 a \\
\pm 0.182\end{array}$ & $\begin{array}{l}6.27 \mathrm{~b} \\
\pm 0.248\end{array}$ & $\begin{array}{l}6.44 b \\
\pm 0.246\end{array}$ & * & $\begin{array}{l}5.30 a \\
\pm 0.193\end{array}$ & $\begin{array}{l}6.21 b \\
\pm 0.214\end{array}$ & $\begin{array}{l}6.25 b \\
\pm 0.279\end{array}$ & ** \\
\hline Feeders of forage & $\begin{array}{l}5.56 \\
\pm 0.203\end{array}$ & $\begin{array}{l}5.73 \\
\pm 0.284\end{array}$ & $\begin{array}{l}6.28 \\
\pm 0.253\end{array}$ & ns & $\begin{array}{l}5.83 a \\
\pm 0.149\end{array}$ & $\begin{array}{l}6.64 b \\
\pm 0.169\end{array}$ & $\begin{array}{l}6.50 \mathrm{~b} \\
\pm 0.230\end{array}$ & ** \\
\hline Watering & $\begin{array}{l}5.75 \\
\pm 0.171\end{array}$ & $\begin{array}{l}5.67 \\
\pm 0.319\end{array}$ & $\begin{array}{l}6.06 \\
\pm 0.235\end{array}$ & ns & $\begin{array}{l}5.52 a \\
\pm 0.226\end{array}$ & $\begin{array}{l}6.21 b \\
\pm 0.187\end{array}$ & $\begin{array}{l}6.25 b \\
\pm 0.305\end{array}$ & $\mathrm{t}$ \\
\hline Faeces consistency (1-5) & $\begin{array}{l}3.88 \\
\pm 0.085\end{array}$ & $\begin{array}{l}3.53 \\
\pm 0.133\end{array}$ & $\begin{array}{l}3.5 \\
\pm 0.146\end{array}$ & ns & $\begin{array}{l}3.48 \\
\pm 0.106\end{array}$ & $\begin{array}{l}3.29 \\
\pm 0.125\end{array}$ & $\begin{array}{l}3,33 \\
\pm 0.188\end{array}$ & ns \\
\hline Body condition score (1-5) & $\begin{array}{l}3.08 \\
\pm 0.067\end{array}$ & $\begin{array}{l}3.05 \\
\pm 0.078\end{array}$ & $\begin{array}{l}3.26 \\
\pm 0.074\end{array}$ & ns & $\begin{array}{l}2.89 \\
\pm 0.088\end{array}$ & $\begin{array}{l}3 \\
\pm 0.106\end{array}$ & $\begin{array}{l}3 \\
\pm 0.092\end{array}$ & ns \\
\hline MAW & $\begin{array}{l}5.66 a \\
\pm 0.293\end{array}$ & $\begin{array}{l}6.11 \mathrm{ab} \\
\pm 0.196\end{array}$ & $\begin{array}{l}6.36 \mathrm{~b} \\
\pm 0.145\end{array}$ & $\mathrm{t}$ & $\begin{array}{l}6.19 \\
\pm 0.141\end{array}$ & $\begin{array}{l}6.44 \\
\pm 0.178\end{array}$ & $\begin{array}{l}6.37 \\
\pm 0.139\end{array}$ & ns \\
\hline FAW & $\begin{array}{l}5.63 a \\
\pm 0.132\end{array}$ & $\begin{array}{l}5.89 \mathrm{ab} \\
\pm 0.210\end{array}$ & $\begin{array}{l}6.26 b \\
\pm 0.163\end{array}$ & * & $\begin{array}{l}5.55 a \\
\pm 0.125\end{array}$ & $\begin{array}{l}6.36 b \\
\pm 0.128\end{array}$ & $\begin{array}{l}6.33 b \\
\pm 0.169\end{array}$ & $* * *$ \\
\hline GAW & $\begin{array}{l}5.76 a \\
\pm 0.172\end{array}$ & $\begin{array}{l}6.12 \mathrm{ab} \\
\pm 0.171\end{array}$ & $\begin{array}{l}6.29 \mathrm{~b} \\
\pm 0.117\end{array}$ & * & $\begin{array}{l}5.90 a \\
\pm 0.109\end{array}$ & $\begin{array}{l}6.32 b \\
\pm 0.117\end{array}$ & $\begin{array}{l}6.20 \mathrm{ab} \\
\pm 0.119\end{array}$ & * \\
\hline
\end{tabular}

Regarding the flock size (Table 4), the GAW ( $p<0.05)$ was below $(5.8 \pm 0.17)$ in small farms in sheep than large $(6.3 \pm$ $0.12)$.

However, the medium goat flocks were better scored $(6.3 \pm$ $0.12)$ than the smaller ones $(5.9 \pm 0.11)$.

Actually, the FAW score present a lower value in small size $(5.6 \pm 0.13)$ of farms to large and medium $(6.4 \pm 0.13)$ in goat $(p<0.001)$ and in sheep in relation to bigger flock size $(6.3 \pm$ $0.16, p<0.05)$ due to the lower score in feeders of concentrate in sheep $(p<0.05)$ and feeders of concentrate, feeders of forage $(p<0.01)$ and watering in goat $(p<0.1)$.
Besides, MAW in sheep was better scored $(p<0.1)$ in larger farms $(6.4 \pm 0.15)$ than the small farms $(5.7 \pm 0.39)$ and animal load got a lower score $(p<0.05)$ in small farms $(5.3 \pm 0.39)$ to medium and large ones $(6.3 \pm 0.23)$. There were not significant differences among flock size in both species for faeces consistency and body condition score parameters.

Table 6 shows the welfare indicators with statistically significant differences between regions, highlighting the differences in the FAW both in sheep and goat.

The different breeds and management peculiarities in each region may explain the differences found. 
Some effects of animal welfare on productive performance were also found. In goats, EAW had a positive and significant correlation (0.358, $p<0.05$ ) with milk fat content and concerning environmental indicators, only temperature had a significant effect on fat $(0.486, p>0.01)$ and fat and protein content $(0.345, p>0.05)$.

Although no significant effects of MAW on production parameters were found, several indicators were correlated with them: in sheep bedding was correlated positively with milk yield $(0.298, p>0.05)$, stress was correlated negatively with somatic cells count $(-0.390, p<0.05)$ and cleanness of animals was correlated positively with fat and protein $(0.347, p$ $<0.05$ ) in sheep and negatively with protein content of milk in goats $(-0.347, p<0.05)$.

Table 6: Animal welfare indicators in sheep and goat by regions.

\begin{tabular}{|c|c|c|c|c|c|c|c|}
\hline & Aragón & Andalucía & Castilla y León & Centro & Valencia & Others & $\mathbf{p}$ \\
\hline \multicolumn{8}{|l|}{ Sheep } \\
\hline \multirow[t]{2}{*}{ Feeders of forage } & $5.33^{a}$ & $5.67^{\mathrm{ab}}$ & $6.08^{\mathrm{ab}}$ & $6.67^{b}$ & $6.00^{\mathrm{b}}$ & $6.00^{\mathrm{ab}}$ & $\mathrm{t}$ \\
\hline & \pm 0.198 & \pm 0.667 & \pm 0.309 & \pm 0.236 & \pm 0.548 & \pm 0.707 & \\
\hline \multirow[t]{2}{*}{ Feces consistency } & $3.83^{b}$ & $3.33^{a b}$ & $3.54^{\mathrm{ab}}$ & $3.67^{b}$ & $3.00^{a}$ & $3.50^{\mathrm{ab}}$ & $*$ \\
\hline & \pm 0.090 & \pm 0.333 & \pm 0.144 & \pm 0.167 & \pm 0.316 & \pm 0.289 & \\
\hline \multirow[t]{2}{*}{ FAW } & $5.57^{\mathrm{a}}$ & $5.44^{a}$ & $6.26^{\mathrm{ab}}$ & $6.41^{\mathrm{b}}$ & $6.20^{\mathrm{ab}}$ & $5.58^{\mathrm{ab}}$ & ** \\
\hline & \pm 0.117 & \pm 0.401 & \pm 0.161 & \pm 0.228 & \pm 0.271 & \pm 0.551 & \\
\hline \multicolumn{8}{|l|}{ Goat } \\
\hline \multirow[t]{2}{*}{ Feeders of concentrate } & $4.50^{\mathrm{a}}$ & $5.77^{\mathrm{ab}}$ & $6.00^{\mathrm{ab}}$ & $6.63^{\mathrm{b}}$ & $6.17^{\mathrm{ab}}$ & $5.41^{\mathrm{ab}}$ & * \\
\hline & \pm 0.500 & \pm 0.257 & \pm 1.000 & \pm 0.324 & \pm 0.167 & \pm 0.211 & \\
\hline \multirow[t]{2}{*}{ FAW } & $5.17^{a}$ & $5.90^{\mathrm{ab}}$ & $6.22^{b}$ & $6.50^{b}$ & $6.22^{b}$ & $5.75^{\mathrm{ab}}$ & * \\
\hline & \pm 0.167 & \pm 0.215 & \pm 0.294 & \pm 0.252 & \pm 0.205 & \pm 0.133 & \\
\hline
\end{tabular}

Regarding FAW, a positive correlation was observed with milk yield $(0.281, p<0.05)$, in sheep. On the other hand, in goat flocks, feeding of concentrate correlated in a negative and significant way with protein milk content $(-0.357, p<$ 0.05 , attributable to a higher concentrate intake, more milk and a dilution effect of higher production in milk solids).

\section{Conclusions}

In view of these results, we can conclude that the assessment of animal welfare in dairy goats and sheep flocks through an evaluation system based on indicators is possible. Besides, we can evaluate and compare animal welfare status among, size of flocks and species. Results obtained show the relationships between the welfare indicators and the zoo technical characteristics of the farms.

In general, indicators related to MAW were the best scored. Concerning size of farms, bigger differences were found in FAW in both species (medium size flocks were the best scored in goat, and large size farms in sheep).

The differences among regions (mainly in indicators of FAW) could be explained by peculiarities of management and breeds of each region.

Moreover, some effects of temperature and feeding in concentrate in milk composition were also found. Bedding was also correlated with milk yield.

In addition, this assessment system allows us to get practical and useful information about which of the animal welfare aspects have more influence on productive performance. Scoring and quantifying the indicators offers the chance to improve every aspect and to check the welfare animal evolution in commercial farms.

\section{References}

1. NEN (2009) Welfare Quality ${ }^{\circledR}$. Assessment protocol for cattle. Netherlands Standardization Institute. Science and society improving animal welfare. Netherlands.

2. Goddard PJ (2013) Small ruminant welfare: Levelling the playing field or raising the bar-A European perspective. Small Ruminant Research 110: 108-111.

3. Mellor DJ, Stafford KJ (2004) Animal welfare implications of neonatal mortality and morbidity in farm animals. The Veterinary Journal 168: 118-133.

4. Wemelsfelder F, Farish M (2004) Qualitative categories for the interpretation of sheep welfare: a review. Animal Welfare 3: 261-268.

5. Rushen J (1986) Aversion of sheep for handling treatments: paired choice experiments. Applied Animal Behaviour Science 16: 363-370.

6. FAWC (2009) Farm animal welfare in Great Britain: past, present and future.

7. Dungey TM (2003) The quantitative and qualitative assessments of behavioural reactions of sheep (Ovis aries) towards feareliciting situations: effects of breed and physiological state. Masters Thesis, University of Edinburgh, UK. 
8. Stillwell G (2015) Practical aspects of management in small ruminants that affect animal welfare: Assessing 's welfare in small ruminant farms. $\mathrm{XL}$ National Congress and $\mathrm{XV}$
International Spanish Society Ovinotecnia and Caprinotecnia (SEOC) 2015. 